\title{
Hematopoietic stem and progenitor cell harvesting: technical advances and clinical utility
}

\section{Olivier Hequet ${ }^{1,2}$}

'Etablissement Français du Sang Rhône Alpes, Apheresis Unit, Centre Hospitalier Lyon Sud France, ${ }^{2}$ Cell Therapy Unit, Etablissement Français du Sang (EFS) Rhône-Alpes, Hospital Edouard Herriot, Lyon, France
Correspondence: Olivier Hequet Banque de tissus et de cellules, Etablissement Français du Sang (EFS), Pavillon I, Hospital Edouard Herriot, 5 Place d'Arsonval, 69003 Lyon, France Tel +33472684620

Fax +3347268462।

Email olivier.hequet@efs.sante.fr

\author{
This article was published in the following Dove Press journal: \\ Journal of Blood Medicine \\ 18 February 2015 \\ Number of times this article has been viewed
}

\begin{abstract}
Hematopoietic stem and progenitor cell (HSPC) transplantations require prior harvesting of allogeneic or autologous HSPCs. HSPCs are usually present in bone marrow $(\mathrm{BM})$ during the entire life, in cord blood (CB) at birth, or in peripheral blood (PB) under particular circumstances. HSPCs were first harvested in BM and later in $\mathrm{CB}$ and $\mathrm{PB}$, as studies showed interesting features of such grafts. All harvesting methods were in use throughout the years, except BM harvesting for HSPC autologous transplantation, which was replaced by PB harvesting. BM, CB, and PB harvesting methods have been developed, and materials and devices technically improved to increase the number of HSPCs harvested. In parallel, knowing the features of the donors or patients associated with successful numbers of HSPCs allows the adaptation of appropriate harvesting methods. Moreover, it is important to ensure the safety of donors or patients while harvesting. This review describes the methods used for harvesting based on recent studies or developments around these methods, and more particularly, the means developed to increase the numbers of HSPCs harvested in each method. It also explains briefly the influence of technical improvements in HSPC harvesting on potential changes in HSPC graft composition.
\end{abstract}

Keywords: hematopoietic stem cell, harvesting, cord blood, bone marrow, mobilization, peripheral blood, apheresis

\section{Introduction}

Hematopoietic stem and progenitor cell (HSPC) transplantation, which was initially considered as an experimental therapy, has been performed and studied over the last 40 years. It has become a referent treatment of severe hematological diseases.

As HSPCs are localized in the bone marrow (BM), the first HSPC transplantations in the 1950s used that as source of cells. ${ }^{1}$ Over the last three decades, allogeneic BM transplantations have become a referent therapy for severe malignant or nonmalignant hematologic diseases. ${ }^{2}$

HSPC transplantations evolved after HSPCs were detected in other sites such as peripheral blood $(\mathrm{PB})$ or cord blood $(\mathrm{CB}) .^{3-5}$ The first allogeneic $\mathrm{CB}$ transplantation was successfully performed at the end of the 1980s. ${ }^{5}$ In parallel, the development of apheresis devices enabled teams to harvest sufficient PB HSPCs for transplantation. Over the last 20 years, numerous HSPC transplantations have been performed. In all types of HSPC transplantations (BM, CB, PB), it was demonstrated that the outcome for the transplanted patients depended on the number of HSPCs contained in the graft. HSPC harvesting methods have, therefore, been improved to transplant higher numbers of HSPCs. In this review, we focus on the recent technical advances in 
HSPC harvesting, recent studies or developments that have brought new knowledge, and their consequences on the graft composition and their clinical utility.

\section{HSPC harvesting methods BM harvesting}

Although HSPC harvesting was performed for the first time more than 50 years ago, BM harvesting was developed mainly to perform allogeneic HSPC transplantations and later autologous transplantations. Nowadays, BM is harvested to perform only allogeneic HSPC transplantation.

\section{Protocol for BM harvesting}

The current protocol recommended for BM harvesting consists in aspirating BM from the posterior iliac crest in a donor under general anesthesia using a needle with multiple side holes, which should be performed by one or two hematologists. The level of aspiration is restricted to 15-20 $\mathrm{mL}$ per puncture into sterile syringes previously rinsed with a heparin/saline solution. While harvesting, regular gentle agitation of the harvesting bag containing an anticoagulant solution prevents clotting. A total nucleated cell (TNC) count performed at midway predicts the optimal $\mathrm{BM}$ volume to be harvested within the limit of the maximum volume. The BM harvested is sent to the cell therapy unit where it is filtered and processed in case of $\mathrm{ABO}$ incompatibility.

The acceptable cell dose harvested in BM and required for allogeneic transplantation is $3-5 \times 10^{8} \mathrm{TNCs}$ per kilogram of recipient body weight (BW). However, when harvesting and transplanting higher numbers of TNCs, better outcomes, such as improved overall survival, were shown in patients. ${ }^{6}$ This occurred particularly in patients allogeneically transplanted for acute myeloid leukemia (AML). ${ }^{6}$ Therefore, hematological teams have developed strategies to harvest higher numbers of TNCs.

\section{How to increase numbers of HSPCs harvested in BM}

It was suggested that priming donors with granulocyte colony-stimulating factor (G-CSF) enhanced the number of TNCs harvested, but that approach was not developed. ${ }^{7}$ Two other ways to harvest higher numbers of BM TNCs and HSPCs, ie, by harvesting larger volumes of BM or by increasing the cell density of the BM harvested, have been developed. The total volume of BM harvested, within the limit of $20 \mathrm{~mL} / \mathrm{kg}$ to prevent excessive blood loss, depends on the donor's BW. In standard procedures, hematologists usually harvest the highest possible volume, which could be deleterious inducing a hemodilution of the BM harvested. Indeed, it was clearly shown that the volume of BM harvested was inversely correlated to the cell density. ${ }^{8}$

To obtain a higher cell density and higher number of cells, it is necessary to change the needle position at short intervals. It is also recommended to optimize the level of aspiration at each site, repetitive aspirations of small volumes of BM enhancing the numbers of TNCs and HSPCs harvested. ${ }^{9}$ Moreover, using needles with multiple side holes combined with harvesting small, repetitive BM volumes induced a high BM cell yield. ${ }^{10,11}$

Parameters other than harvesting techniques, such as the characteristics of donors, could influence the cell density and numbers of TNCs in the BM harvested. Among them, the donor BW and baseline white blood cell (WBC) levels were correlated to the cell density in BM harvests. ${ }^{8}$ Other characteristics, including lower age and cytomegalovirus-negative donors, smoking, higher hemoglobin and mononuclear cell blood levels, higher number of whole blood donations in the year preceding the BM harvest, and higher body surface area, were associated with higher numbers of TNCs harvested in BM. ${ }^{12}$ A higher hemoglobin level, higher number of whole blood donations, and smoking were probably associated with a more active hematopoiesis.

\section{CB harvesting}

$\mathrm{CB}$ at delivery was found to contain HSPCs. ${ }^{4,13}$ These HSPCs displayed interesting features such as high-potential clonogenicity, but their absolute numbers were, however, not sufficient for allogeneic transplantation in adults and were only appropriate to transplant low-BW recipients, ie, children. ${ }^{5}$ Such allogeneic transplantations displayed advantages over allogeneic BM and PB HSPC transplantations, such as low incidence of graft-versus-host-disease. Considering the advantages of $\mathrm{CB}$ transplantations, hematologic teams created a European organization for $\mathrm{CB}$ banking. ${ }^{14}$ The aim was to allow transplantation from unrelated children and possibly from low-BW adults if the numbers of cells contained in $\mathrm{CB}$ units (CBU) were sufficient for transplantation. For that purpose, the numbers of HSPCs harvested in CBUs had to be increased by optimizing harvesting methods or obstetrical conditions. In 2005, an American team developed the concept of transplanting two CBUs partially matched together, which induced lower duration of aplasia and fewer infectious complications than after single CBU transplantations in adults. ${ }^{15}$ This reinforced the need for standardizations in the stages of the CBU banking process and for studies to increase the number of HSPCs in CBUs. 


\section{Protocol for $C B$ harvesting}

The initial method for harvesting $\mathrm{CB}$ was described at the end of the 1980s. ${ }^{13}$ Although a few attempts were made to improve it, the current protocol recommended is very similar to the initial protocol and is described as follows: After the birth of the infant, the umbilical cord is double-clamped from the umbilicus and transacted between the clamps. The umbilical cord vein is punctured under sterile conditions, and the blood flows freely by gravity into an anticoagulated sterile closed harvesting system. ${ }^{16,17}$ Birth unit staff should be trained in $\mathrm{CB}$ harvesting to reduce the rejection rate due to labeling problems, bacterial contamination, and clotting. ${ }^{16}$ The mean volume and numbers of HSPCs harvested in CBU can vary from one study to another, but can be described as follows: $108 \pm 28 \mathrm{~mL}, 12.5 \pm 5.3 \times 10^{8} \mathrm{TNC}$, and $3.6 \pm 3.3 \times 10^{6}$ CD34+ cells. ${ }^{18}$ The harvest must be stored and transported under controlled temperature. The time interval between CBU harvesting and processing is limited to $24-36$ hours corresponding to sufficient cell viability.

\section{How to increase numbers of HSPCs harvested in $C B$}

Initially, the numbers of HSPCs contained in CBUs or transplanted were defined by measuring the numbers of TNCs and colony forming unit-granulocyte macrophage (CFU-GM). ${ }^{5,13}$ After 2000, the CD34+ immunomarker was used to characterize the population of HSPCs contained in $\mathrm{BM}, \mathrm{PB}$, and in $\mathrm{CBU}$, in addition to TNCs. ${ }^{19} \mathrm{~A}$ strong correlation was found between the numbers of HSPCs and the CB volume harvested..$^{20,21}$ Obstetrical and technical methods were then developed to harvest the highest possible volume of $\mathrm{CB}$. $\mathrm{CB}$ volume was initially considered as - and was later proven to be - one of the best predictive data for acceptable CBU banking. ${ }^{20,21}$

A variety of potential $\mathrm{CB}$ harvesting methods have been described to harvest large volumes of CB. Closed, semiclosed, and open systems were developed using blood bags, syringes/ flushed or not, or drains/flushed or not, with no significant difference in the harvested volume. ${ }^{22,23}$ Since 1998, the US Food and Drug administration (FDA) invited professional groups to submit proposed standards, data, and information to have available CBUs appropriate for allogeneic transplantation. Providers developed systems to obtain more CBU volume and TNCs harvested (Table 1). Some systems were likely to increase the volume or the numbers of cells harvested, but these were not extensively used, and the protocol for $\mathrm{CB}$ harvesting remained as described above.

In order to increase the volumes and numbers of cells harvested, obstetrical teams assessed and compared CB harvesting methods. CB can be harvested before or after the placenta delivery, ie, in utero or ex utero, and during cesarean. In utero, harvesting is done by midwives in the delivery room, the placenta being compressed by the uterus at the third stage of labor. Ex utero, harvesting is done by cord bank employees in an adjacent room right after the placental delivery. Therefore, the obstetrical CB harvesting methods vary from one team to another (Table 1). Some studies have shown higher volumes and HSPC numbers when harvested in utero, while other studies have shown comparable volumes and HSPCs numbers in both conditions. ${ }^{18,29-31}$ Both methods have advantages and disadvantages, which generated controversies. Therefore, early cord clamping is associated with higher volumes harvested, but this may hamper the normal process of delivery. Harvesting CB after delivery is easier, but only lower volumes can be harvested. Moreover, comparisons between harvests performed during vaginal and cesarean delivery showed either identical numbers or higher numbers of HSPCs harvested during the latter. ${ }^{32,33}$

The factors that influence the yield of CB volume and cells have been studied. Therefore, primigravidae, higher birth weight, Caucasian race, young (34-37 weeks) or old (40 weeks), gestational age, and female sex were associated with higher volumes and numbers of CD34+ cells harvested..$^{20,33,34}$ Prenatal sonografic parameters can estimate fetal weight and are correlated with CB hematological parameters. ${ }^{35}$ Knowledge of these factors will help in banking and harvesting $\mathrm{CB}$ efficiently, but the banking levels depend on the cell threshold and strategy of each CB bank. The main reason for excluding the CBUs harvested is the low volume or low numbers of cells contained in a CBU. The other reasons for excluding the $\mathrm{CBU}$ are preparation or logistical complications, abnormal biological result in donor, and CBU microbial infection (Table 2). ${ }^{18,36,37}$ The rate of CBU microbial contamination varies from $0 \%$ to $48 \%{ }^{23,24,38}$

In order to limit the exclusion of the CBUs, it is necessary to select suitable donors. Successful selection requires the collection of accurate information when gathering and obtaining informed consent from the mother. Parents with previous history of cancers or hematologic, genetic, or autoimmune diseases are excluded from donation. Serological tests (for hepatitis, human immunodeficiency virus [HIV], cytomegalovirus, syphilis, and Epstein-Barr virus) must be performed in the mother's blood at delivery. However a genetic, hematologic, or oncological disease can occur in newborns several years after $\mathrm{CB}$ harvesting and storing, which requires information about the $\mathrm{CB}$ donor's health before sending the $\mathrm{CBU}$ for transplantation. 
Table I Recent studies performed to improve amounts of hematopoietic stem and progenitor cell (HSPC) harvested in cord blood (CB)

\begin{tabular}{|c|c|c|c|c|}
\hline Type of improvement & Reference & Year & Goal & Results \\
\hline \multirow[t]{5}{*}{ Technical } & Elchalal et $\mathrm{a}^{24}$ & 2000 & $\begin{array}{l}\text { Compare three methods of harvesting } \\
\text { process (with or without flushing by } \\
\text { a syringe and sodium chloride into an } \\
\text { open sterile container or a blood bag). } \\
\text { Results on volume, TNC, and bacterial } \\
\text { contamination }\end{array}$ & $\begin{array}{l}\text { Flushing increased the volume and total nucleated cell } \\
\text { (TNC) numbers } \\
\text { Bacterial contamination was lower when harvesting in } \\
\text { a blood bag }\end{array}$ \\
\hline & $\begin{array}{l}\text { Belvedere } \\
\text { et } \mathrm{a}^{25}\end{array}$ & 2000 & $\begin{array}{l}\text { Evaluate a harvesting system (pressure } \\
\text { application system) by inducing } \\
\text { additional pressure after delivery }\end{array}$ & $\begin{array}{l}\text { Increase in volume and CD } 34+\text { cell numbers ( } 40 \%) \text {. } \\
\text { The last fraction harvested by the device contained } \\
\text { more HSPCs than the first fraction harvested by gravity }\end{array}$ \\
\hline & $\begin{array}{l}\text { Bornstein } \\
\text { et } \mathrm{al}^{26}\end{array}$ & 2005 & $\begin{array}{l}\text { Evaluate a second fraction harvested } \\
\text { after placenta perfusion }\end{array}$ & $\begin{array}{l}\text { This fraction contributed to } 32 \% \text { volume and } 15 \% \text { TNC } \\
\text { of the whole } C B \text { unit }\end{array}$ \\
\hline & Takebe et $\mathrm{al}^{27}$ & 2009 & $\begin{array}{l}\text { Describe a pulsatile machine } \\
\text { reperfusion of a placenta to improve } \\
\text { harvesting yield }\end{array}$ & Improved harvest with 1.5 -fold increase in CD34+ cells \\
\hline & Tan et $\mathrm{al}^{28}$ & 2012 & $\begin{array}{l}\text { Describe an auto-perfusing CB } \\
\text { harvesting instrument }\end{array}$ & $\begin{array}{l}\text { Generate vibrations during the perfusion phase and a } \\
\text { control platform to integrate all systems }\end{array}$ \\
\hline \multirow[t]{6}{*}{ Obstetrical } & Surbek et $\mathrm{al}^{29}$ & 1998 & $\begin{array}{l}\text { A randomized comparison of harvest } \\
\text { while placenta is still in the uterus } \\
\text { before vs after placenta delivery }\end{array}$ & $\begin{array}{l}\text { More volume and mononuclear cells harvested before } \\
\text { placenta delivery }\end{array}$ \\
\hline & Larsky et $\mathrm{al}^{30}$ & 2002 & $\begin{array}{l}\text { Compare the CB harvest while } \\
\text { placenta is still in the uterus vs after } \\
\text { placental delivery }\end{array}$ & $\begin{array}{l}\text { Both methods produced comparable hematological } \\
\text { parameters (volume, TNC, CD34+, CFU-GM) }\end{array}$ \\
\hline & Solves et al ${ }^{18}$ & 2003 & $\begin{array}{l}\text { Compare the CB harvest in the } \\
\text { delivery room (while placenta is still } \\
\text { in the uterus) vs in an adjacent room } \\
\text { after placental delivery }\end{array}$ & $\begin{array}{l}\text { CB harvesting before placental delivery allows the best } \\
\text { TNC and HSPC harvest }\end{array}$ \\
\hline & Wong et $\mathrm{al}^{3 !}$ & 2001 & $\begin{array}{l}\text { Compare the CB harvest in the } \\
\text { delivery room (while placenta is still } \\
\text { in the uterus) vs in an adjacent room } \\
\text { after placental delivery }\end{array}$ & $\begin{array}{l}\text { CB harvesting before placental delivery allows the best } \\
\text { TNC and HSPC yield }\end{array}$ \\
\hline & Omori et $\mathrm{al}^{32}$ & 2010 & $\begin{array}{l}\text { Compare } \mathrm{CB} \text { collection in cesarean } \\
\text { and vaginal delivery }\end{array}$ & $\begin{array}{l}\text { Higher volume when cesarean, but higher CD34+ cells } \\
\text { after vaginal delivery }\end{array}$ \\
\hline & Cairo et $\mathrm{a}^{33}$ & 2005 & $\begin{array}{l}\text { Analyze the factors associated with } \\
\text { better cell yields }\end{array}$ & Cesarean section is associated to higher total CFU \\
\hline
\end{tabular}

Abbreviations: GM, granulocyte macrophage; CFU, colony forming unit.

In 1998, the foundation NetCord was developed to establish an international registry for CB banks and procedures with standards for the safe exchange and transplantation use of CBU. In 2000, the NetCord Foundation for the

Table 2 Reasons for excluding the CBUs harvested

\begin{tabular}{ll}
\hline Exclusion criteria & $\%$ \\
\hline Low volume or low total nucleated cell amounts & $52-85$ \\
Bacterial cord blood unit (CBU) contaminations & $5-17$ \\
Storage/transport time $>48 \mathrm{~h}$ & $\mathrm{I}-16$ \\
Abnormal transport temperature & $\mathrm{I}-2$ \\
Incomplete documentation in hospital & $2-3$ \\
Parents medical history & $2-5$ \\
Abnormal maternal infectious disease testing & $\mathrm{I}-5$ \\
Problems during CBU processing & $3-5$ \\
Clots & $2-4$ \\
\hline
\end{tabular}

Notes: Data from recent unpublished experience in France and three large cohorts recently published with, respectively, 7,92I CBUs harvested and 2,014 CBUs stored; 3I,I28 CBUs harvested and 7,056 CBUs stored; and II70 CBUs harvested and 735 CBUs stored. ${ }^{17,36,37}$
Accreditation of Cellular Therapy released international standards for accreditation not only for harvesting but also for testing, processing, and storing CBU. ${ }^{39}$

\section{PB HSPC harvesting: mobilization and apheresis techniques}

The presence of HSPCs in PB was detected in $1971 .{ }^{3}$ In parallel, over the last decades, the development of apheresis devices has allowed the harvesting of PB HSPCs. As no HSPCs are present or detected in $\mathrm{PB}$ under normal conditions, it is necessary to mobilize HSPCs from BM to PB. These mobilization treatments are not the same in donors for allogeneic transplantations and in patients for autologous transplantations.

\section{HSPC mobilization in healthy donors}

Related or unrelated donors usually receive G-CSF (filgrastim or lenograstim) $10 \mu \mathrm{g} / \mathrm{kg} /$ day from $4-5$ days before 
apheresis. ${ }^{40}$ The factors associated with a better efficiency in mobilizing $\mathrm{CD} 34+$ cells are male sex, higher body mass index, higher G-CSF dosage, higher premobilization WBC, and the use of lenograstim rather than filgrastim. ${ }^{41,42}$ Higher age, female sex, white ethnicity, and donors lighter than their recipient are factors associated with a poorer mobilization. ${ }^{43,44}$ Knowing the risk factors for poor mobilization allows processing larger blood volume or anticipating a possible rescue by BM harvesting. It is difficult to determine the percentage of donors who fail to mobilize an adequate number of HSPCs for harvest because this minimal number is different among centers. In case of insufficient mobilization and, therefore, insufficient HSPCs harvest, the BM harvest rescue can be replaced by using a new mobilization agent named plerixafor, but this treatment is not approved by the FDA and in most countries. ${ }^{45}$

\section{HSPC mobilization in patients}

The following three broad strategies are usually followed to mobilize HSPCs from BM to PB in patients:

1. Combined chemotherapies associated with the hematopoietic growth factor, ie, G-CSF currently used to treat the underlying disease, ie, Hodgkin's disease (HD), nonHodgkin lymphoma (NHL), or solid tumors, and inducing aplasia allow mobilization of CD34+ cells into PB. ${ }^{46-48}$ Randomized studies have shown that doubling the dose of filgrastim improved the CD34+ cell harvest and decreased the median number of apheresis procedures. ${ }^{49}$

2. Cyclophosphamide associated with hematopoietic growth factors can be used in the treatment of multiple myeloma (MM) and HSPC mobilization. Mobilization by cyclophosphamide after new chemotherapy regimen is possible, although some of these agents (thalidomide, lenalidomide) were suspected to cause harvest failure. ${ }^{50,51}$ Randomized studies have shown that the addition of growth factors (GM-CSF or G-CSF) to cyclophosphamide resulted in a significant increase in the numbers of CD34+ cells harvested. ${ }^{52}$ The use of biosimilar G-CSF instead of G-CSF seemed to induce the same levels of CD34+ HSPCs harvested and the same harvesting duration. ${ }^{53}$

3. Mobilization by hematopoietic growth factors alone can be efficiently used to mobilize HSPCs. Randomized studies compared growth factors, ie, filgrastim to molgramostim and to pegfilgrastim, without demonstrating any superiority for a growth factor or a scheme..$^{54,55}$

Over the last 15 years, numerous studied have shown the factors that affect HSPC mobilization, ie, age, sex, underlying disease, interval between diagnosis and harvest, exposure to alkylating agents, prior irradiation, marrow involvement, blood-platelets baseline, and cancer relapse (Table 3). ${ }^{56-62}$ Megakaryocyte-platelet lineage is particularly sensitive to damage in the BM microenvironment. Therefore, premobilization blood platelet baseline appears to be an indicator for autologous HSPC mobilization. ${ }^{59,61}$ Moreover, agents (thalidomide, bortezomib or lenalidomide, and fludarabine) used in new therapeutic schemes could affect HSPC mobilization. Indeed, the number of HSPCs harvests after short courses of chemotherapy using these agents is lower than when control groups receive

Table 3 Main factors that may negatively affect successful HSPC harvest

\begin{tabular}{|c|c|c|c|}
\hline Factors & Results & Commentary & Reference \\
\hline \multirow[t]{2}{*}{ Older age } & 58 years was the cutoff & Study performed in myeloma patients & Lacativa et $\mathrm{a}^{61}$ \\
\hline & 70 years has been described as another cutoff & Factor also described in other diseases & \\
\hline \multirow[t]{2}{*}{ Diagnosis } & NHL, myeloma and AML were alternatively & More difficult in AML patients & Mendrone et $\mathrm{al}^{59}$ \\
\hline & described & & Koenigsmann et $\mathrm{al}^{60}$ \\
\hline Prior irradiation & Mainly bone irradiation & Factors described in $M M$ and in most studies & Bensinger et $\mathrm{al}^{56}$ \\
\hline Bone marrow & Presence and importance of involvement & Factors described in most studies & Bensinger et $\mathrm{al}^{56}$ \\
\hline involvement & & Factors described in most diseases & Cesaro et $\mathrm{al}^{48}$ \\
\hline Stage of the disease & Advanced stage & Factors described in NHL and cancers & Weaver et $\mathrm{al}^{57}$ \\
\hline Number of previous & More than three lines of chemotherapy & Fewer lines are associated to better harvest & Bensinger et $\mathrm{al}^{56}$ \\
\hline \multirow[t]{2}{*}{ chemotherapy regimens } & & Factor also described as chemotherapy load & Ketterer et $\mathrm{al}^{58}$ \\
\hline & & & Mendrone et $\mathrm{al}^{59}$ \\
\hline \multirow[t]{2}{*}{ Alkylating agents } & Cisplatin is described in most studies & Factors associated to the number of & Mendrone et $\mathrm{al}^{59}$ \\
\hline & Mitoxantrone is described & chemotherapy cycles & \\
\hline \multirow[t]{2}{*}{ Platelet baseline count } & Cutoff: I50,000-16I,000 platelets/ $\mu \mathrm{L}$ & Factors described in most recent studies & Mendrone et $\mathrm{al}^{59}$ \\
\hline & & & Lacativa et $a^{61}$ \\
\hline \multirow[t]{2}{*}{ Fludarabine exposure } & Exposure to several lines & Factor described in $\mathrm{NHL}$ & Ketterer et $\mathrm{al}^{58}$ \\
\hline & & Factor confirmed in most studies & Waterman et $\mathrm{al}^{62}$ \\
\hline Cancer relapse & More difficult to harvest when relapse & $\begin{array}{l}\text { Factors associated to other factors (lines of } \\
\text { chemotherapy) }\end{array}$ & Cesaro et $\mathrm{al}^{48}$ \\
\hline
\end{tabular}

Abbreviations: AML, acute myeloid leukemia; MM, multiple myeloma; NHL, non-Hodgkin lymphoma; HSPC, hematopoietic stem and progenitor cell. 
older combination of chemotherapies. Moreover, fludarabine exposure hampers adequate HSPC mobilization probably by causing stem cell damage. ${ }^{58,62}$ However, the regimen used to treat MM does not significantly hamper HSPC mobilization during G-CSF or during cyclophosphamide mobilization. ${ }^{63,64}$ Knowing all these factors will enable teams to feature poor mobilizers (PMs).

There is no consensus on the definition of PM patients. The patients in whom poor mobilization induces HSPC harvest failure for low blood peak of circulating CD34+ cells associated or not with factors likely to affect HSPC mobilization were named PMs. The patients suspected to become PMs were named predicted PMs. The criteria used for defining the status of PM were different among different studies (Table 4). Whatever the definition or the criteria chosen, the overall incidence of mobilization failure varies from $5 \%$ to $40 \%$. ${ }^{67-69}$

Table 4 Definition and criteria of poor mobilizers (PMs)

\begin{tabular}{llll}
\hline Reference & Year & Definition & Incidence \\
\hline $\begin{array}{l}\text { Predicted PM } \\
\text { Li et al }{ }^{65}\end{array}$ & 201 II & $\begin{array}{l}\text { Lower than I5 CD34+ circulating } \\
\text { cells } / \mu \mathrm{L} \text { while WBC count is }\end{array}$ \\
& $>10 \times 10^{9} / \mathrm{L}$
\end{tabular}

Abbreviations: BW, body weight; HSPC, hematopoietic stem and progenitor cell; $\mathrm{Nd}$, not determined; PMs, poor mobilizers; WBC, white blood cell.

\section{How to manage poor mobilizers}

After revealing a PM patient, different solutions can be used to perform appropriate mobilization.

1. BM harvesting is no more used to perform autologous HSPC harvests because it was proven to be ineffective in patients with insufficient PB HSPC mobilization and/ or harvest. ${ }^{70}$

2. Remobilization can be performed with high-dose chemotherapy associated with growth factors or with growth factors only. ${ }^{71}$

3. High-dose administration of growth factors can be used following the principle of dose-dependent response to mobilization. ${ }^{72,73}$

4. Stem cell factor has been successfully used in combination with G-CSF to mobilize HSPCs. ${ }^{74}$ Stem cell factor is the ligand for c-kit, which is a membrane receptor with tyrosine kinase activity expressed on several tissues including the hematopoietic system. This treatment induced adequate harvest in $40 \%$ of PMs. ${ }^{75}$

5. More recently, the use of plerixafor has demonstrated encouraging results. Plerixafor is a reversible inhibitor of HSPC adhesion to stromal cells by CXCR4 binding to stromal-derived factor-1. The best scheme for using plerixafor consists in combining it with mobilization by G-CSF. This treatment induces rates of successful CD34+ cell harvests in 70\% of NHL, HD, and MM PMs. ${ }^{76}$ Combining plerixafor with pegfilgrastim or with mobilizing chemotherapy seems safe and effective in PMs, but these results require confirmative data. ${ }^{77}$ The main disadvantage of plerixafor is its cost, requiring the development of algorithms for the use of plerixafor in autologous HSPC mobilization. ${ }^{78}$

After mobilizing HSPCs from BM to PB, the apheresis teams have to harvest them from PB.

\section{PB HSPC harvesting by apheresis}

The purpose of apheresis sessions during treatment for NHL, HD, or MM is to harvest enough HSPCs to perform autologous transplantation in the patient. The most relevant number of HSPCs to be harvested is $4 \times 10^{6} \mathrm{CD} 34+$ cells $/ \mathrm{kg}$ BW for treating NHL patients and $4 \times 10^{6} \mathrm{CD} 34+$ cells $/ \mathrm{kg} \mathrm{BW}$ per graft for treating MM patients by harvesting one or two grafts. In all diseases, the minimum number of HSPCs to be harvested is $2 \times 10^{6} \mathrm{CD} 34+/ \mathrm{kg} \mathrm{BW}$ for each graft.

To perform allogeneic HSPC transplantations, apheresis sessions are performed in an human leukocyte antigen (HLA)-compatible donor after checking the absence of infectious, oncological, autoimmune, and vascular diseases. 
The number of HSPCs to be harvested varies depending on the teams and nature of the transplantation (non-myelo, myelo-ablative, or haplo-identical), ie, from 4 to $10 \times 10^{6}$ CD34+ cells/kg recipients' $\mathrm{BW}$.

A strong correlation was found between pre-apheresis PB CD34+ cell counts combined or not with the numbers of CD34+ cells harvested at mid-point and numbers of CD34+ cells harvested after the corresponding apheresis sessions. ${ }^{79,80}$ The analysis of these pre-apheresis blood levels allows apheresis teams to adapt the blood volume processed and potentially perform large-volume leukapheresis. ${ }^{81}$

\section{Apheresis techniques}

Different apheresis devices have been developed to harvest PB HSPCs. All these techniques share a common process, ie, separating blood components in layers by centrifugation and harvesting blood-mobilized HSPCs in a particular layer associated with other blood cells. The principles of the main and current apheresis techniques are summarized in Table 5. Over the last 30 years, the COBE Spectra has been considered as the main apheresis device used to harvest PB HSPCs by most apheresis teams. ${ }^{82,83}$ This technique was extensively used with the Manual Collection Protocol. Later, an automated version of COBE Spectra, named Auto-PBSC, was developed and operated with cyclical harvest of a mononuclear cell fraction. ${ }^{84}$

Studies have compared the performances of the devices (Table 6) ${ }^{82,85-90}$ Indexes were developed to characterize the performances of the devices during harvesting. The main index is the collection efficiency (CE). Other indexes (platelets or hemoglobin losses, apheresis duration, contamination with nontargeted cells) were analyzed. ${ }^{88-90}$
CEs were similar in both protocols (manual and Auto-PBSC) developed for COBE Spectra. ${ }^{84}$ The platelet loss was lower with the Auto-PBSC than with the Manual COBE Spectra technique. ${ }^{84}$ The comparison of the performances of Fenwal Amicus and COM.TEC showed identical CE ${ }^{85}$ Compared to the Haemonetics MCS+ or to the Baxter Amicus, a shorter apheresis duration and a better correlation between PB preapheresis CD34+ cell counts and numbers of CD34+ cells harvested were shown with COBE Spectra. ${ }^{82,83}$

The COBE Spectra technique is being replaced by a new technique, the Spectra Optia. ${ }^{86}$ A comparison of the performances between COBE Spectra, Spectra Optia, and COM. TEC techniques showed higher CE in both Spectra Optia and COM.TEC techniques, but Spectra Optia sessions required longer durations. ${ }^{87,88}$

\section{How to manage poor HSPC harvest by apheresis}

The HSPC harvest depends on the pre-apheresis circulating CD34+ cell counts, performances of the apheresis techniques, and the blood volume processed. Each of these elements can be improved. After unsuccessful mobilization, the unfavorable situation can be quickly corrected by using plerixafor in a salvage administration. ${ }^{65,91}$ The old devices gave the opportunity to improve the harvest manually, while new devices perform the task automatically. Another solution consists in processing more blood volumes during the apheresis sessions. In the past, apheresis sessions consisted of processing large volumes. ${ }^{81}$ Such approach was safe, but a significant decrease in blood electrolyte concentration and platelets had to be prevented. ${ }^{92}$ Studies considering the possibility to perform large-volume leukapheresis with the new devices should be carried out.

Table 5 Main current apheresis techniques used for hematopoietic stem and progenitor cell (HSPC) harvest

\begin{tabular}{|c|c|c|c|c|}
\hline & COBE Spectra & Spectra Optia & Amicus & COM.TEC \\
\hline Firm & TerumoBCT (Lakewood, Co) & TerumoBCT (Lakewood, Co) & Fenwall (Lake Zurich, IL) & $\begin{array}{l}\text { Fresenius Healthcare (Bad } \\
\text { Homburg, Germany) }\end{array}$ \\
\hline Flow method & Continuous & Continuous & Continuous & Continuous \\
\hline Blood separation & $\begin{array}{l}\text { Continuous separation of } \\
\text { blood components }\end{array}$ & $\begin{array}{l}\text { Continuous blood separation } \\
\text { monitored by automated } \\
\text { interface management (AIM) }\end{array}$ & $\begin{array}{l}\text { Continuous blood } \\
\text { separation monitored by } \\
\text { two sensors }\end{array}$ & $\begin{array}{l}\text { Blood separation is } \\
\text { performed during cycles } \\
\text { whose features are } \\
\text { individually determined }\end{array}$ \\
\hline HSPC harvest & $\begin{array}{l}\text { Continuous harvest of the } \\
\text { mononuclear cells layer }\end{array}$ & $\begin{array}{l}\text { Harvest in a collection } \\
\text { chamber and line during cycles }\end{array}$ & $\begin{array}{l}\text { Harvest in a collection } \\
\text { chamber and line }\end{array}$ & $\begin{array}{l}\text { Intermittent harvest } \\
\text { at the end of each } \\
\text { separation cycle }\end{array}$ \\
\hline $\begin{array}{l}\text { Operator } \\
\text { adjustment }\end{array}$ & $\begin{array}{l}\text { Continuous manual adjustment } \\
\text { of the interface and the harvest }\end{array}$ & $\begin{array}{l}\text { Interface and harvest } \\
\text { automatically controlled with } \\
\text { few adjustments }\end{array}$ & $\begin{array}{l}\text { Interface and harvest } \\
\text { automatically controlled }\end{array}$ & $\begin{array}{l}\text { Adjusting the volumes of } \\
\text { the separation cycle, buffy } \\
\text { coat, and spillover }\end{array}$ \\
\hline
\end{tabular}

Note: A modified automatic COBE Spectra technique was also developed and named Auto-PBSC. 
Table 6 Recent studies comparing the performances of apheresis devices for HSPC harvesting

\begin{tabular}{|c|c|c|c|}
\hline Reference (year) & Goal & $\begin{array}{l}\text { Number of } \\
\text { procedures }\end{array}$ & Results \\
\hline Altuntas et $\mathrm{a}^{85}$ (2007) & $\begin{array}{l}\text { Compare Amicus and COM.TEC } \\
\text { performances }\end{array}$ & $\begin{array}{l}\text { Amicus: } 20 \\
\text { COM.TEC: } 20\end{array}$ & $\begin{array}{l}\text { No difference in numbers of CD34+ cells } \\
\text { harvested } \\
\text { Higher decrease in PB platelets with COM.TEC }\end{array}$ \\
\hline Reinhardt et al ${ }^{86}(2011)$ & $\begin{array}{l}\text { Evaluate performances of Spectra } \\
\text { Optia and comparison with historical } \\
\text { performances of COBE Spectra }\end{array}$ & $\begin{array}{l}\text { Spectra Optia: } 35 \\
\text { COBE Spectra: } 401\end{array}$ & $\begin{array}{l}\text { Excellent usability of Spectra Optia } \\
\text { CE2 superior with Spectra Optia }\end{array}$ \\
\hline Wu et $\mathrm{al}^{82}(2012)$ & $\begin{array}{l}\text { Compare HSPC harvest using COBE } \\
\text { Spectra, MCS+ Haemonetics, and Baxter } \\
\text { Amicus }\end{array}$ & $\begin{array}{l}\text { COBE Spectra: } 99 \\
\text { MCS+: } 81 \\
\text { Amicus: } 38\end{array}$ & $\begin{array}{l}\text { Similar number of CD34+ cells harvested } \\
\text { Better correlation of harvested/circulating } \\
\text { HSPCs with COBE Spectra. Amicus collected } \\
\text { less platelets }\end{array}$ \\
\hline Brauninger et $\mathrm{al}^{87}(20 \mid 2)$ & $\begin{array}{l}\text { Compare Spectra Optia and COBE } \\
\text { Spectra performances }\end{array}$ & $\begin{array}{l}\text { Spectra Optia: } 50 \\
\text { COBE Spectra: } 89\end{array}$ & $\begin{array}{l}\text { With Optia } \\
\text { - CEI: } 7.9 \% \text { greater } \\
\text { - Less platelets but more granulocytes in } \\
\text { products }\end{array}$ \\
\hline $\begin{array}{l}\text { Flommersfeld et al }{ }^{88} \\
(20 \mid 3)\end{array}$ & $\begin{array}{l}\text { Compare COM.TEC, COBE Spectra, } \\
\text { and Spectra Optia }\end{array}$ & $\begin{array}{l}\text { COM-TEC: } 77 \\
\text { Spectra Optia: } 52 \\
\text { COBE Spectra: } 58\end{array}$ & $\begin{array}{l}\text { With Optia: } \\
\text { - Higher CE } \\
\text { - Longer duration }\end{array}$ \\
\hline Ikeda et al ${ }^{89}(2014)$ & $\begin{array}{l}\text { Compare Spectra-MNC (manual) and } \\
\text { Spectra Auto-PBSC performances }\end{array}$ & $\begin{array}{l}\text { Spectra-Auto: } 118 \\
\text { Spectra-MNC: } 70\end{array}$ & $\begin{array}{l}\text { Correlation between circulating HSPCs and } \\
\text { harvested HSPCs in Spectra - MNC } \\
\text { Less reduction in PB platelets in Spectra-Auto }\end{array}$ \\
\hline Cherqaoui et $\mathrm{al}^{90}(2014)$ & $\begin{array}{l}\text { Compare Spectra Optia and COBE } \\
\text { Spectra performances in low-weight } \\
\text { children }\end{array}$ & $\begin{array}{l}\text { Spectra Optia: } 8 \\
\text { COBE Spectra: } 22\end{array}$ & $\begin{array}{l}\text { Similar CE } \\
\text { Reduced platelet and Hb loss with Spectra } \\
\text { Optia but higher duration }\end{array}$ \\
\hline
\end{tabular}

Note: Two collection efficiency (CE) indexes are described: CD34 CEI $(\%)=$ absolute number of CD34+ cells harvested $(\times 100 \%) /([$ pre-apheresis $C D 34+$ blood levels + post-apheresis CD34+ blood levels]/2) $\times$ total processed volume; CD34 CE2 (\%) = absolute number of CD34+ cells harvested $(\times 100 \%) / p r e-a p h e r e s i s ~ C D 34+$ blood levels $\times$ total processed volume.

Abbreviations: $\mathrm{Hb}$, hemoglobin; HSPC, hematopoietic stem and progenitor cell; PB, peripheral blood.

\section{How to ensure safety of donors BM harvest}

The safety of BM donors must be ensured during and after harvesting. Knowing donors' medical history and clinical evaluation enables medical teams to prevent occurrence of complications during general anesthesia. It is possible to harvest BM after local anesthesia associated or not with analgesia. ${ }^{93}$ Decreases in blood red cell levels are linked to the volume of BM harvested and can be treated by iron supplementation or by autologous red cell transfusion. After the donation, donors usually complain of bone pain. The complications and quality of life in adult and pediatric BM donors must be evaluated. ${ }^{94}$

\section{CB harvest}

When harvesting $\mathrm{CB}$, it is essential to ensure safety to both the mother and the infant. The CB harvest must be performed after the delivery. The safe management of obstetric delivery should never be compromised to facilitate CB harvest. ${ }^{16}$ The umbilical CB clamping should not be performed too early after delivery to prevent deprivation in blood volume and hemodynamic disturbances in the infant. ${ }^{95}$

\section{PB harvest}

Ensuring safety is important for allogeneic donors of PB HSPCs. In this setting, three elements must be considered, ie, the immediate side effects after mobilization by G-CSF or new agents, side effects during apheresis, and long-term side-effects of the mobilizing agents. G-CSF stimulation induces pain (bone, muscle, headache) until the end of stimulation. Donors with higher WBC levels experience more fatigue; females experience headache, nausea, and fever; and higher G-CSF dosage is associated with bone pain. ${ }^{96} \mathrm{G}-\mathrm{CSF}$ induces sometimes high WBC levels, which could generate vascular complications. Indeed, splenic rupture, which is a rare complication, has been observed in allogeneic and autologous donors. ${ }^{97}$ When WBC is higher than $60,000 / \mu \mathrm{L}$, a GSF dose adaptation can be proposed to prevent vascular complications.

The second element concerns the apheresis itself. In a minor proportion of donors $(0.6 \%-20 \%$ depending on the apheresis center), a central venous catheter may be necessary. ${ }^{98}$ Pain at the site of puncture occurs more frequently in donors with a central (58\%) than peripheral vein access (38\%). ${ }^{99}$ The occurrence of acute side effects in large series of BM and PB HSPC harvests in donors has 
been compared, which showed that peak levels of pain and toxicities were comparable in both harvesting methods. ${ }^{100}$

The incidence of complications (cancer, autoimmune disease, and thrombosis) was similar after BM and PB HSPC donation $\left(0.99 \%\right.$ vs $0.31 \%$, respectively). ${ }^{101}$ The long-term safety of G-CSF in donors is still being debated. G-CSF induces epigenetic and cytogenetic abnormalities, which persist for several months. ${ }^{102}$ The donor immune response is disturbed during 6 months, with decrease in T-cell PB counts due to the apheresis, and also in interleukin (IL)-2 and IL-10 production due to G-CSF. ${ }^{103}$ Long-term medical and biological follow-up are necessary to confirm the safety of G-CSF in donors.

When harvesting PB in patients, the intensity of the main symptoms or complications from G-CSF stimulation and apheresis can be confused with the symptoms from the chemotherapy-induced aplasia. Plerixafor can induce transient side effects (diarrhea, nausea, injection site erythema, headache, paresthesia). The long-term side effects of plerixafor should be studied in particular, if this treatment is to be used in routine or in donors.

\section{Cell composition of graft and influence on HSPC transplantations Clinical consequence of BM graft composition}

BM contains HSPCs that are the main cell population to be transplanted, but other cells must be considered for hematopoietic transplantations.

In harvested BM, stromal cells and the marrow microenvironment are associated with HSPCs, and both are important to reconstitute $\mathrm{BM}$ in nononcological hematological diseases and diseases with marrow abnormalities. When the main aim is to obtain a graft-versus-leukemia (GVL) effect, PB and not BM HSPCs are preferentially harvested. The recent development of haplo-identical transplantations followed by posttransplantation cyclosphamide injection has reintroduced the interest for using BM. ${ }^{104} \mathrm{BM}$ was also used after solidorgan or composite-tissue transplantation to induce immune tolerance. ${ }^{105}$

\section{Clinical consequence of $\mathrm{CBU}$ composition}

The use of CBUs for allogeneic HSPC transplantation is associated with lower incidence of graft-versus-host-disease with slow immune and hematological recovery, inducing high incidence of opportunistic or severe viral infections. The transplantations of two CBUs decrease the incidence of these complications. ${ }^{15}$ The numbers of HSPCs transplanted are associated with the outcome. The relation between lymphocyte composition in transplanted $\mathrm{CB}$ and outcome after transplantation is currently being studied. ${ }^{106}$

\section{Clinical consequence of PB graft composition}

During allogeneic transplantation, a PB graft is harvested when a GVL effect is aimed. Indeed, during apheresis, both HSPCs and lymphocytes (which participate in the GVL effect) are harvested in the same layer. This feature is used when harvesting allogeneic donor lymphocytes for infusion to reinforce the GVL effect. This principle has been developed in reduced intensity conditioning of allogeneic transplantations.

The PB autologous HSPC harvesting process is performed either in first-line or first-relapse poor-prognosis NHL, in $\mathrm{HD}$, and in first-line treatment for MM or some solid tumors (neuroblastoma or brain tumors). The number of HSPCs transplanted is associated with a better outcome in patients treated for NHL and MM. ${ }^{107,108}$ In addition to HSPCs, the PB harvests contain significant numbers of lymphocytes that influence the immune reconstitution after transplantation. The numbers of $\mathrm{T}$ and NK cells are higher in grafts after mobilization with plerixafor than after standard mobilization. ${ }^{109}$ Studies should be carried out to determine whether autologous grafts mobilized with plerixafor are associated with a better outcome or to changes in immune reconstitution.

\section{Conclusion}

HSPC transplantations have become a referent treatment of severe hematological diseases and gives opportunities to obtain a long-term remission. The number of HSPCs infused during the transplantation is predictive of a better outcome in most types of diseases and hematopoietic transplantations. Therefore, as a first and main step in transplantations, the harvest must contain enough autologous or allogeneic HSPCs. Besides standard HSPC harvesting protocols, harvesting methods and techniques have been improved over the years. Studies also brought better knowledge of the factors associated with better harvests.

When considering BM transplantations with improved harvesting techniques, the latest studies have focused on the evaluation of the complications and quality of life of donors. On the other side, properties of stromal cells and their interaction with HSPCs have been characterized. Such knowledge has generated new indications for using BM transplantation to induce immune tolerance. The characterization of the 
interactions between HSPCs and stromal cells has led to target the pathways involved in HSPC mobilization from $\mathrm{BM}$ to blood. Treatments have been developed to increase mobilization targeting these interactions. Plerixafor is the prototype of these new mobilizing agents. In the next few years, other new mobilizing agents targeting such interactions will be developed, but their cost will require the development of algorithms to use them.

The development of new mobilization agents has enabled teams to harvest autologous HSPCs in almost all patients. Autologous transplantation is therefore now possible for a majority of patients, inducing very low failure of HSPC harvests. Further studies should show whether such harvesting possibilities can change the prognosis of PM patients who need an autologous HSPC transplantation. The development of CBU transplantation and banks should improve the chances of performing successful allogeneic HSPC transplantations in patients without (HLA-) related or unrelated donors.

In conclusion, to increase the success of HSPC transplantations, it is necessary to continue improving the harvesting techniques, numbers of HSPCs, and clinical consequences in patients or donors, which emphasizes the major role of the teams performing HSPC harvesting. Indeed, this purpose can be achieved with further studies based on their work and carried out on a regular basis.

\section{Disclosure}

The authors report no conflicts of interest in this work.

\section{References}

1. Thomas ED, Lochte HL Jr, Cannon JH, Sahler OD, Ferrebee JW. Supralethal whole body irradiation and isologous marrow in man. JClin Invest. 1959;38:1709-1716.

2. Armitage JO. Bone marrow transplantation. $N$ Eng J Med. 1994; 330(12):827-838.

3. McCredie KB, Hersh EM, Freirich EJ. Cells capable of colony formation in the peripheral blood of man. Science. 1971;171(3968): 293-294.

4. Lu L, Xiao M, Shen RN, Gribgsby S, Broxmeyer HE. Enrichment, characterization, and responsiveness of single primitive cord blood hematopoietic progenitors with high proliferative and replating potential. Blood. 1993;81(1):41-48.

5. Gluckman E, Broxmeyer H, Auerbach A, et al. Hematopoietic reconstitution in a patient with Fanconi's anemia by means of umbilicalcord blood from an HLA-identical sibling. N Engl J Med. 1989; 321(17):1174-1178.

6. Rocha V, Labopin M, Gluckman E, et al; Acute Leukemia Working Party of the European Blood and Marrow Transplant Registry. Relevance of bone marrow cell dose on allogeneic transplantation outcomes for patients with acute myeloid leukemia in first complete remission: results of a European survey. J Clin Oncol. 2002;20(21):4324-4330.

7. Isola LM, Scigliano E, Skerrett D, et al. A pilot study of allogeneic bone marrow transplantation using related donors stimulated with G-CSF. Bone Marrow Transplant. 1997;20(12):1033-1037.
8. Kao RH, Li CC, Shaw CK, et al. Correlation between characteristics of unrelated bone marrow donor and cell density of total nucleated cell in bone marrow harvest. Int J Hematol. 2009;89(2):227-230.

9. Bacigalupo A, Tong J, Podesta M, et al. Bone marrow harvest for marrow transplantation: effect of multiple small $(2 \mathrm{~mL})$ or large $(20 \mathrm{~mL})$ aspirates. Bone Marrow Transplant. 1992;9(6):467-470.

10. Wang TF, Chu SC, Chen SH, et al. The effect of different harvest strategies on the nucleated cell yields of bone marrow collection. Biol Blood Marrow Transplant. 2011;17(3):351-355.

11. Tanikawa S, Sakamaki H, Mori S, et al. Relationship between the presence of side-holes in bone marrow aspiration needle and the number of harvested bone marrow mononuclear cells. Rinsho Ketsueki. 1997;38(12):1249-1253.

12. Bouwmeester W, Fechter MM, Heymans MW, Twisk JW, Ebeling LJ, Brand A. Prediction of nucleated cells in bone marrow stem cell products by donor characteristics: a retrospective single centre analysis. Vox Sang. 2010;98(3):276-283.

13. Broxmeyer HE, Douglas GW, Hangoc G, et al. Human umbilical cord blood as a potential source of transplantable hematopoietic stem/ progenitor cells. Proc Natl Acad Sci U S A . 1989;86(10):3828-3832.

14. Gluckman E. European organization for cord blood banking. Blood Cells. 1994;24(2-3):601-608.

15. Barker JN, Weisdorf DJ, DeFor TE, et al. Transplantation of 2 partially HLA-matched umbilical cord blood units to enhance engraftment in adults with hematologic malignancy. Blood. 2005;105(3):1343-1347.

16. Armson BA. Maternal/fetal medicine committee, society of obstetricians and gynaecologists of Canada. Umbilical cord blood banking: implications for perinatal care providers. J Obstet Gynaecol Can. 2005;27(3):263-290.

17. Lauber S, Latta M, Klüter H, Müller-Steinhardt M. The Mannheim Cord Blood Bank: experiences and perspectives for the future. Transfus Med Hemother. 2010;37(2):90-97.

18. Solves P, Moraga R, Saucedo E, et al. Comparison between two strategies for umbilical cord blood collection. Bone Marrow Transplant. 2003;31(4):269-273.

19. Aroviita P, Teramo K, Westman P, Hiilesmaa V, Kekomäki R. Associations among nucleated cell, CD34+ cell and colony-forming cell contents in cord blood units through a standardized banking process. Vox Sang. 2003;84(3):219-227.

20. Page KM, Mendizabal A, Betz-Stablein B, et al. Optimizing donor selection for public cord blood banking: influence of maternal, infant, and collection characteristics on cord blood unit quality. Transfusion. 2014;54(2):340-352.

21. Keersmaekers CL, Mason BA, Keersmaekers J, Ponzini M, Mlyanarek RA. Factors affecting umbilical cord blood stem cell suitability for transplantation in an in utero collection program. Transfusion. 2014;54(3):545-549.

22. Fasouliotis SJ, Schenker MD. Human umbilical cord blood banking and transplantation: a state of the art. Eur J Obstet Gynecol Reprod Biol. 2000;90(1):13-25.

23. Bertolini F, Lazzari L, Lauri E, et al. A comparative study of different procedures for the collection and banking of umbilical cord blood. J Hematother. 1995;4(1):29-36.

24. Elchalal U, Fasouliotis SJ, Shtockheim D, et al. Postpartum umbilical cord blood collection for transplantation: a comparison of three methods. Am J Obstet Gynecol. 2000;182(1):227-232.

25. Belvedere O, Feruglio C, Malangone W, et al. Increased blood volume and CD34+CD38- cell recovery using a novel umbilical cord blood collection system. Stem Cells. 2000;18(4):245-251.

26. Bornstein R, Flores AI, Montalbán MA, Del Rey D, de la Serna J, Gilsanz F. A modified cord blood collection method achieves sufficient cell levels for transplantation in most adult patients. Stem Cells. 2005;23(3):324-334.

27. Takebe N, Gage F, Cheng X, Lauw MIS. Preliminary findings on the use of a pulsatile machine reperfusion of a placenta to improve the cord blood collection yield including primitive hematopoietic stem cell fractions. Transfusion. 2009;49(9):1911-1916. 
28. Tan KK, Tang KZ, Huang S, et al. Ex utero harvest of hematopoietic stem cells from placenta/umbilical cord with an automated collection system. IEEE Trans Biomed Eng. 2009;56(9):2331-2334.

29. Surbek DV, Schönfeld B, Tichelli A, Gratwohl A, Holzgreve W. Optimizing cord blood mononuclear cell yield: a randomized comparison of collection before vs after placenta delivery. Bone Marrow Transplant. 1998;22(3):311-312.

30. Lasky LC, Lane TA, Miller JP, et al. In utero or ex utero cord blood collection: which is better? Transfusion. 2002;42(10):1261-1267.

31. Wong A, Yuen PM, Li K, Tsoi WC. Cord blood collection before and after placental delivery: levels of nucleated cells, haematopoietic progenitor cells, leukocyte subpopulations and macroscopic clots. Bone Marrow Transplant. 2001;27(2):133-138.

32. Omori A, Manabe M, Kudo K, Tanaka K, Takahashi K, Kashiwakura I. Influence of obstetric factors on the yield of mononuclear cells, CD34+ cell count and volume of placental/umbilical cord blood. J Obstet Gynaecol Res. 2010;36(1):52-57.

33. Cairo MS, Wagner EL, Fraser J, et al. Characterization of banked umbilical cord blood hematopoietic progenitor cells and lymphocyte subsets and correlation with ethnicity, birth weight, sex, and type of delivery: a Cord Blood Transplantation (COBLT) Study report. Transfusion. 2005;45(6):856-866

34. Jan RH, Wen SH, Shyr MH, Chiang BL. Impact of maternal and neonatal factors on CD34+ cell count, total nucleated cells, and volume of cord blood. Pediatr Transplant. 2008;12(8): 868-873.

35. Cobellis L, Castaldi MA, Trabucco E, et al. Cord blood unit bankability can be predicted by prenatal sonographic parameters. Eur J Obstet Gynecol Reprod Biol. 2013;170(2):391-395.

36. Liu J, He J, Chen S, et al. Cord blood banking and transplantation in China: a ten years experience of a single public bank. Transfus Med Hemother. 2012;39(1):23-27.

37. Jawdat D, Arab S, Thahery H, Almashaqbeh W, Alaskar A, Hajeer AH Improving cord blood unit quantity and quality at King Abdullah International Medical Research Center Cord Blood Bank. Transfusion. Epub June 9, 2014.

38. Clark P, Trickett A, Stark D, Vowels M. Factors affecting microbial contamination rate of cord blood collected for transplantation. Transfusion. 2012;52(8):1770-1777.

39. Warkentin PI. Foundation for the accreditation of cellular therapy. Voluntary accreditation of cellular therapies: foundation for the accreditation of cellular therapy (FACT). Cytotherapy. 2003;5(4): 299-305.

40. Anguita-Compagnon AT, Dibarrart MT, Palma J, et al. Mobilization and collection of peripheral blood stem cells: guidelines for blood volume to process, based on CD34-positive blood cell count in adults and children. Transplant Proc. 2010;42(1):339-344.

41. Chen J, Burns KM, Babic A, et al. Donor body mass index is an important factor that affects peripheral blood progenitor cell yield in healthy donors after mobilization with granulocyte-colony-stimulating factor. Transfusion. 2014;54(1):203-210.

42. Bertani G, Santoleri L, Martino M, et al. Identification of hematopoietic progenitor cell donor characteristics predicting successful mobilization results in an Italian multicenter study. Transfusion. 2014;54(8): 2028-2033.

43. Al-Ali HK, Bourgeois M, Krahl R, et al. The impact of the age of HLA-identical siblings on mobilization and collection of PBSCs for allogeneic hematopoietic cell transplantation. Bone Marrow Transplant. 2011;46(10):1296-1302.

44. Billen A, Madrigal JA, Szydlo RM, Shaw BE. Female donors and donors who are lighter than their recipient are less likely to meet the CD34+ cell dose requested for peripheral blood stem cell transplantation. Transfusion. Epub May 27, 2014.

45. Hauge AW, Haastrup EK, Sengeløv H, Minulescu L, Dickmeiss E, Fischer-Nielsen A. Addition of plerixafor for CD34+ cell mobilization in six healthy stem cell donors ensured satisfactory grafts for transplantation. Transfusion. 2014;54(4):1055-1058.
46. de Latour RP, Chaoui D, Bourhis JH, et al. Mobilization of peripheral blood progenitor cells after DHAP regimen with or without rituximab: a large multicenter comparative study in patients with malignant lymphoma. Leuk Lymphoma. 2007;48(5):897-904.

47. Endo T, Sato N, Mogi Y, et al. Peripheral blood stem cell mobilization following CHOP plus rituximab therapy combined with G-CSF in patients with B-cell non-Hodgkin's lymphoma. Bone Marrow Transplant. 2004;33(7):703-707.

48. Cesaro S, Tintori V, Nesi F, et al. A prospective study on the efficacy of mobilization of autologous peripheral stem cells in pediatric oncohematology patients. Transfusion. 2013;53(7):1501-1509.

49. Sheppard D, Bredeson C, Allan D, Tay J. Systematic review of randomized controlled trials of hematopoietic stem cell mobilization strategies for autologous transplantation for hematological malignancies. Biol Blood Marrow Transplant. 2012;18(8):1191-1203.

50. Jung SH, Park H, Ahn JS, et al. Efficacy of stem cell mobilization in patients with newly diagnosed multiple myeloma after a CTD (cyclophosphamide, thalidomide, and dexamethasone) regimen. Int $J$ Hematol. 2013;97(1):92-97.

51. Bhutani D, Zonder J, Valent J, et al. Evaluating the effects of lenalidomide induction therapy on peripheral stem cells collection in patients undergoing autologous stem cell transplant for multiple myeloma. Support Care Cancer. 2013;21(9):2437-2442.

52. Martínez E, Sureda A, Dalmases CD, et al. Mobilization of peripheral blood progenitor cells by cyclophosphamide and rhGM-CSF in multiple myeloma. Bone Marrow Transplant. 1996;18(1):1-7.

53. Publicover A, Richardson DS, Davies A, et al. Use of biosimilar granulocyte colony-stimulating factor for peripheral blood stem cell mobilization: an analysis of mobilization and engraftment. $\mathrm{Br} J$ Haematol. 2013;162(1):107-111.

54. Weisdorf D, Miller J, Verfaillie C, et al. Cytokine-primed bone marrow stem cells vs peripheral blood stem cells for autologous transplantation: a randomized comparison of GM-CSF vs G-CSF. Biol Blood Marrow Transplant. 1997;3(4):217-223.

55. Herbert KE, Gambell P, Link EK, et al. Pegfilgrastim compared with filgrastim for cytokine-alone mobilization of autologous haematopoietic stem and progenitor cells. Bone Marrow Transplant. 2013;48(3):351-356.

56. Bensinger W, Appelbaum F, Rowley S, et al. Factors that influence collection and engraftment of autologous peripheral-blood stem cells. $J$ Clin Oncol. 1995;13(10):2547-2555.

57. Weaver CH, Schwartzberg LS, Birch R, et al. Collection of peripheral blood cells after the administration of cyclophosphamide, etoposide, and granulocyte-colony-stimulating factor: an analysis of 497 patients. Transfusion. 1997;37(9):896-903.

58. Ketterer N, Salles G, Moullet I, et al. Factors associated with successful mobilization of peripheral blood progenitor in 200 patients with lymphoid malignancies. Br J Haematol. 1998;103(1):235-242.

59. Mendrone A, Arrais CA, Saboya R, Chamone DAF, Dulley FL. Factors affecting hematopoietic progenitor cell mobilization: an analysis of 307 patients. Transfus Apher Sci. 2008;39(3):187-192.

60. Koenigsmann M, Jentsch-Ullrich K, Mohren M, Becker E, Heim M, Franke A. The role of diagnosis in patients failing peripheral blood progenitor cell mobilization. Transfusion. 2004;44(5):777-784.

61. Lacativa CP, Lacativa PG, Garnica M, et al. Risk factors for unsuccessful peripheral blood stem cell harvesting using granulocyte-colony stimulating factor mobilization in patients with multiple myeloma. Transfus Apher Sci. 2012;47(3):331-335.

62. Waterman J, Rybicki L, Bolwell B, et al. Fludarabine as a risk factor for poor stem cell harvest, treatment-related MDS and AML in follicular lymphoma patients after autologous hematopoietic cell transplantation. Bone Marrow Transplant. 2012;47(4):488-493.

63. Moreau P, Hulin C, Marit G, et al. Stem cell collection in patients with de novo multiple myeloma treated with the combination of bortezomib and dexamethasone before autologous stem cell transplantation according to IFM 2005-01 trial. Leukemia. 2010;24(6): 1233-1235. 
64. Cavallo F, Bringhen S, Milone G, et al. Stem cell mobilization in patients with newly diagnosed multiple myeloma lenalidomide induction therapy. Leukemia. 2011;25(10):1627-1631.

65. Li J, Hamilton E, Vaughn L, et al. Effectiveness and cost analysis of "just in time" salvage plerixaflor administration in autologous transplant patients with poor stem cell mobilization kinetics. Transfusion. 2011;51(10):2175-2182.

66. Attolico I, Pavone V, Ostuni A, et al. Plerixafor added to chemotherapy plus G-CSF is safe and allows adequate PBSC collection in predicted poor mobilizer patients with multiple myeloma or lymphoma. Biol Blood Marrow Transplant. 2012;18(2):241-249.

67. Olivieri A, Marchetti M, Lemoli R, et al. Proposed definition of 'poor mobilizer' in lymphoma and multiple myeloma: an analytic hierarchy process by ad hoc working group Gruppo ItalianoTrapianto di Midollo Osseo. Bone Marrow Transplant. 2012;47(3):342-351.

68. Perseghin P, Terruzzi E, Dassi M, et al. Management of poor peripheral blood stem cell mobilization: incidence, predictive factors, alternative strategies and outcome. A retrospective analysis on 2177 patients from three major Italian institutions. Transfus Apher Sci. 2009;41(1): 33-37.

69. Wuchter P, Ran D, Bruckner T. Poor mobilization of hematopoieic stem cells-definition, incidence, risk factors, and impact on outcome of autologous transplantation. Biol Blood Marrow Transplant. 2010;16(4):490-499.

70. Watts MJ, Sullivan AM, Leverett D, et al. Back-up bone marrow is frequently ineffective in patients with poor peripheral-blood stem-cell mobilization. J Clin Oncol. 1998;16(4):1554-1560.

71. Reiser M, Josting A, Draube A, et al. Successful peripheral blood stem cell mobilization with etoposide (VP-16) in patients with relapsed or resistant lymphoma who failed cyclophosphamide mobilization. Bone Marrow Transplant. 1999;23(12):1223-1228.

72. Lie AK, Hui CH, Rawling T, et al. Granulocyte colony-stimulating factor (G-CSF) dose-dependent efficacy in peripheral blood stem cell mobilization in patients who had failed initial mobilization with chemotherapy and G-CSF. Bone Marrow Transplant. 1998;22(9): 853-857.

73. Pérez-Dueñas B, Alcorta I, Estella J, Rives S, Toll T, Tuset E. Safety and efficacy of high-dose G-CSF (24 microg/kg) alone for PBSC mobilization in children. Bone Marrow Transplant. 2002;30(12): 987-988.

74. Facon T, Harousseau JL, Maloisel F, et al. Stem cell factor in combination with filgrastim after chemotherapy improves peripheral blood progenitor cell yield and reduces apheresis requirements in multiple myeloma patients: a randomized controlled trial. Blood. 1999;94(4):1218-1225.

75. Lapierre V, Rossi JF, Heshmati F, et al. Ancestim (r-metHuSCF) plus filgrastim and/or chemotherapy for mobilization of blood progenitors in 513 poorly mobilizing cancer patients: the French compassionate experience. Bone Marrow Transplant. 2011;46(7):936-942.

76. Shaughnessy P, Uberti J, Devine S, et al. Plerixafor and G-CSF for autologous stem cell mobilization in patients with NHL, Hodgkin's lymphoma and multiple myeloma: results from the expanded access program. Bone Marrow Transplant. 2013;48(6):777-781.

77. Herbert KE, Demosthenous L, Wiesner G, et al. Plerixafor plus pegfilgrastim is a safe, effective mobilization regimen for poor or adequate mobilizers of hematopoietic stem and progenitor cells: a phase I clinical trial. Bone Marrow Transplant. 2014;49(8):1056-1062.

78. Costa LJ, Alexander ET, Hogan KR, Schaub C, Fouts TV, Stuart RK. Development and validation of a decision-making algorithm to guide the use of plerixafor for autologous hematopoietic stem cell mobilization. Bone Marrow Transplant. 2011;46(1):64-69.

79. Schots R, Van Riet I, Damiaens S, et al. The absolute number of circulating CD34+ cells predicts the number of haematopoietic stem cells that can be collected by apheresis. Bone Marrow Transplant. 1996;17(4):509-515.

80. Lane TA, Bashey A, Carrier E, et al. Improving the efficiency of PBPC collection by pre-apheresis peripheral blood and mid-apheresis product measurements of CD34 cells. Cytotherapy. 2004;6(4):318-327.
81. Menichella G, Lai M, Serafini R, et al. Large volume leukapheresis for collecting hemopoietic progenitors: role of CD 34+ precount in predicting successful collection. Int J Artif Organs. 1999;22(5):334-341.

82. Wu FY, Heng KK, Salleh RB, et al. Comparing peripheral blood stem cell collection using the COBE Spectra, Haemonetics MCS+, and Baxter Amicus. Transfus Apher Sci. 2012;47(3):345-350.

83. Ikeda K, Ohto H, Nemoto K, et al. Collection of MNCs and progenitor cells by two separators for PBPC transplantation: a randomized crossover trial. Transfusion. 2003;43(6):814-819.

84. Schreiner T, Wiesneth M, Krug E, et al. Collection of allogeneic peripheral blood progenitor cells by two protocols on an apheresis system. Transfusion. 1998;38(11-12):1051-1055.

85. Altuntas F, Kocyigit I, Ozturk A, et al. Comparison of the Fenwal Amicus and Fresenius Com.Tec cell separators for autogous peripheral blood progenitor cell collection. Transfus Apher Sci. 2007;36(2):159-167.

86. Reinhardt P, Brauninger S, Bialleck H, et al. Automatic inter-face controlled apheresis collection of stem/progenitor cells: results from an autologous donor validation trial of a novel stem cell apheresis device. Transfusion. 2011;51(6):1321-1330.

87. Brauninger S, Bialleck H, Thorausch K, Felt T, Seifried E, Bonig H. Allogeneic donor peripheral blood "stem cell" apheresis: prospective comparison of two apheresis systems. Transfusion. 2012; 52(5):1137-1145.

88. Flommersfeld S, Bakchoul T, Bein G, Wachtel A, Loechelt C, Sachs UJ. A single center comparison between three different apheresis systems for autologous and allogeneic stem cell collections. Transfus Apher Sci. 2013;49(3):428-433.

89. Ikeda K, Ohto H, Kanno T, et al. Peripheral blood cell progenitor cell collection by two programs for autologous and allogeneic transplantation. Transfusion. 2014;54(5):1235-1242.

90. Cherqaoui B, Rouel N, Auvrignon A, et al. Peripheral blood stem collection in low-weight children: retrospective comparison of two apheresis devices. Transfusion. 2014;54(5):1371-1378.

91. Andreola G, Vanazzi A, Radice D, et al. Who should be really considered as a poor mobilizer in the plerixafor era? Transfus Apher Sci. 2012;47(1):27-32.

92. Bojanic I, Dubravcic K, Batinic D, et al. Large volume leukapheresis: efficacy and safety of processing patient's total blood volume six times. Transfus Apher Sci. 2011;44(2):139-147.

93. $\mathrm{Ng} \mathrm{HN}$, Sim KM, Boey SK. Bone marrow harvesting using EMLA (eutectic mixture of local anaesthesics) cream, local anaesthesia and patient-controlled analgesia with alfentanil. Bone Marrow Transplant. 1999;23(9):941-945.

94. van Walraven SM, Straathof LM, Switzer GE, et al. Immediate and long-term somatic effects, and health-related quality of life of BM donation during early childhood. A single-center report in 210 pediatric donors. Bone Marrow Transplant. 2013;48(1):40-45.

95. Lazzari L, Corsini C, Curioni C, et al. The Milan Cord Blood Bank and the Italian Cord Blood Network. J Hematother. 1996;5(2):117-122.

96. Chen SH, Yang SH, Chu SC, et al. The role of donor characteristics and post-granulocyte colony-stimulating factor white blood cell counts in predicting the adverse events and yields of stem cell mobilization. Int J Hematol. 2011;93(5):652-659.

97. Akyol G, Pala C, Yildirim A, et al. A rare but severe complication of filgrastim in a healthy donor: splenic rupture. Transfus Apher Sci. 2014;50(1):53-55.

98. Pulsipher MA, Chitphakdithai P, Miller JP, et al. Adverse events among 2408 unrelated donors of peripheral blood stem cells: results of a prospective trial from the National Marrow Donor Program. Blood. 2009;113(15):3604-3611.

99. Hölig K, Blechschmidt M, Kramer M, et al. Peripheral blood stem cell collection in allogeneic donors: impact of venous access. Transfusion. 2012;52(12):2600-2605.

100. Pulsipher MA, Chitphakdithai P, Logan BR, et al. Acute toxicities of unrelated bone marrow versus peripheral blood stem cell donation: results of a prospective trial from the National Marrow Donor Program. Blood. 2013;121(1):197-206. 
101. Pulsipher MA, Chitphakdithai P, Logan BR, et al. Lower risk for serious adverse events and no increased risk for cancer after PBSC vs BM donation. Blood. 2014;123(23):3655-3663.

102. Marmier-Savet C, Larosa F, Legrand F, et al. G-CSF-induced aneuploidy does not affect CD34+ cells and does not require cell division. Blood. 2010;115(4):910-911.

103. Marmier-Savet C, Larosa F, Legrand F, et al. Persistence of lymphocyte function perturbations after granulocyte-colony-stimulating factor mobilization and cytapheresis in normal peripheral blood stem cell donors. Transfusion. 2010;50(12):2676-2685.

104. Raiola AM, Dominietto A, di Grazia C, et al. Unmanipulated haploidentical transplants compared with other alternative donors and matched sibling grafts. Biol Blood Marrow Transplant. 2014; 20(10):1573-1579.

105. Kawai T, Sachs DH, Sprangers B, et al. Long-term results in recipients of combined HLA-mismatched kidney and bone marrow transplantation without maintenance immunosuppression. Am J Transplant. 2014;14(7):1599-1611.
106. Wikell H, Ponandai-Srinivasan S, Mattsson J, Gertow J, Uhlin M. Cord blood graft composition impacts the clinical outcome of allogeneic stem cell transplantation. Transpl Infect Dis. 2014;16(2): 203-212.

107. Gordan LN, Sugrue MW, Lynch JW, et al. Poor mobilization of peripheral blood stem cells is a risk factor for worse outcome in lymphoma patients undergoing autologous stem cell transplantation. Leuk Lymphoma. 2003;44(5):815-820.

108. Wahlin A, Eriksson M, Hultdin M. Relation between harvest success and outcome after autologous peripheral blood stem cell transplantation in multiple myeloma. Eur J Haematol. 2004;73(4):263-268.

109. Varmavuo V, Mäntymaa P, Nousiainen T, Valonen P, Kuittinen T, Jantunen E. Blood graft composition after plerixafor injection in patients with NHL. Eur J Haematol. 2012;89(2):128-135.
Journal of Blood Medicine

\section{Publish your work in this journal}

The Journal of Blood Medicine is an international, peer-reviewed, open access, online journal publishing laboratory, experimental and clinical aspects of all topics pertaining to blood based medicine including but not limited to: Transfusion Medicine; Blood collection, Donor issues, Transmittable diseases, and Blood banking logistics; Immunohematology; Artificial and alternative

\section{Dovepress}

blood based therapeutics; Hematology; Biotechnology/nanotechnology of blood related medicine; Legal aspects of blood medicine; Historical perspectives. The manuscript management system is completely online and includes a very quick and fair peer-review system. Visit http://www.dovepress.com/ testimonials.php to read real quotes from published authors.

Submit your manuscript here: http://www.dovepress.com/Journal-of-blood-medicine-journal 